\title{
Grants for Japan's top twelve with physicists favoured
}

Tokyo

JAPAN's Ministry of Education, Culture and Science (MESC) will give out more than $¥ 2,500$ million ( $\$ 17$ million) in "special, distinguished grants" to a handful of researchers this year, up by a massive $¥ 700$ million from last year. As in previous years, molecular biology features prominently, taking five of the twelve awards. But the biggest grants go to highenergy and solid-state physics and the new field of high-temperature superconductors.

The awards are the most significant and lucrative in MESC's repertoire and are intended for "internationally recognized research likely to produce outstanding results". Each award runs for 3-5 years and is largely used for the purchase of equipment and materials. The salaries of the half dozen or so key researchers on each project are paid separately by the ministry.

Peptide research is a favourite this year. Shigetada Nakanishi of Kyoto University, who receives $¥ 204$ million over four years, will investigate regulation of bradykinin, neuropeptides and the angiotensinrenin system both in vitro and in vivo (using transgenic mice) and will try to clone the peptide receptors. Hisayuki Matsuo of Miyazaki Medical College gets $¥ 223$ million, also for four years, to search for peptides involved in "bio-communication" (the chemical transfer of information within organisms). Similarly, cell signalling will feature in a three-year study

\section{New angle on flight}

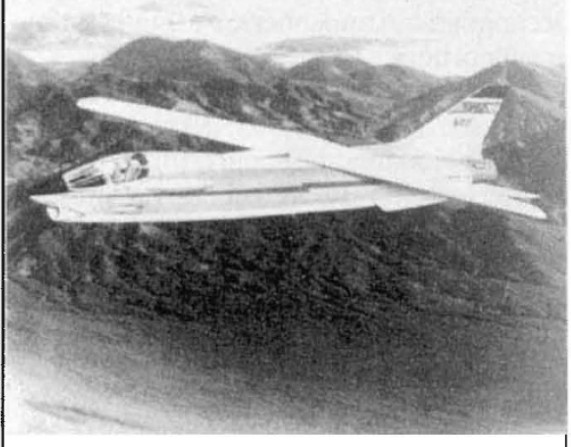

Thrs is not a mistake, but what the US aviation company Rockwell intends to do to an F-8 Crusader aircraft. An oblique-wing aircraft, according to aerodynamics theory, might not create a sonic boom at low supersonic speeds. Drag is reduced too, as the lift of the wing is distributed over the long streamwise length. Finally, a boon in naval applications, an oblique-wing aircraft would be much more convenient for stowage in below-deck hangars. of GTP-binding protein by Yoshito Kaziro of Tokyo University.

But the biggest grant in bioscience goes to Nobutaka Hirokawa of Tokyo University to study the cytoskeleton, in particular of nerve cells. Hirokawa, who gave up a university post in the United States to return to Japan, is one of the pioneers of quick-freeze electron microscopy and he will use this technique and micro-injection of proteins and antibodies to examine the molecular architecture and dynamics of the cytoskeleton, and localized developmental processes in the cell.

Physicists, however, run off with the biggest grants of all. Yoichi Iwasaki of Tsukuba University gets $¥ 278$ million over three years to calculate the masses of hadrons, such as the $\mathrm{H}$ particle, using numerical simulation based on lattice gauge theory. And Noriaki Ito of Nagoya University receives a similar amount over five years to probe alkali halides, semiconductors and ceramics with lasers and electron beams in an attempt to elucidate electron-photon interactions.

But in solid-state physics, the award of $¥ 258$ million to Shoji Tanaka of Tokyo University is attracting the most attention. Tanaka heads the group at Tokyo University that confirmed high-temperature superconductivity in copper oxide ceramics at the end of last year, following their discovery by scientists at IBM Zurich. And the Ministry of Education is making considerable financial commitments to this group's research. Earlier this year, the ministry took the extraordinary step of extending a special project grant headed by Professor Nakajima, one of Tanaka's colleagues, by injecting a further $¥ 160$ million (over $\$ 1$ million) for the study of oxide superconductors. And Professor Kazuo Fueki, another of the Tokyo University group, was also awarded $¥ 36$ million for this fiscal year.

Further substantial funding from the ministry (for high-temperature superconductor research) can be expected. Simultaneously with the announcement of this year's special distinguished grants, the ministry released details of projects selected as "priority areas of research" in fiscal year 1988. Among them is one on high-temperature superconductors headed by Yoshio Muto of Tohoku University, who also has close links with the Tokyo University group.

Although the number of participants and amount of funds have yet to be fixed, about $60-70$ researchers are expected to join Muto's project and funding will probably be in the middle of the range for such projects ( $¥ 50$ to $¥ 600$ million), according to a ministry official. David Swinbanks

\section{Superphénix on hold}

THE French prototype Superphénix fastbreeder reactor is still in trouble. The leak of liquid sodium from a storage tank that was first noticed in March has yet to be located. The tank will now be drained and a search made for the leak by pumping helium into the space between the tank and its outer protective shell. Auditory detectors should pick up the escaping gas.

Officials at the Superphénix site, near Lyons, strongly deny that faulty workmanship is responsible for the leak. Mr Horst Weber, a construction foreman at Superphénix ten years ago, had claimed in the German magazine Stern that welding work had sometimes been botched.

P.C.

\section{More animals spared}

THE number of laboratory experiments using animals is declining in Britain, according to the latest statistics, and is now the lowest for $\mathbf{3 0}$ years. About 80 per cent of the 3.1 million animal experiments carried out in 1986 involved mice or rats, and the number of primates used has dropped by about a third in the past decade, to 5,600 experiments, mainly for studying medicines. New legislation should further reduce animal experimentation. K.J.

\section{Acid rain deposition}

AcID rain deposition in the United Kingdom declined in the first half of the $1980 \mathrm{~s}$, according to a new report from the UK Review Group on Acid Rain. But levels of hydrogen and sulphate deposition in the high-rainfall areas of Cumbria and the Scottish Highlands remain high, comparable with those in the acidified areas of Norway. Emissions of sulphur dioxide have declined overall, with a proportional reduction in deposition. Hydrogen-ion deposition has dropped by 25 per cent, although nitrogen oxides have not changed since 1970.

The review group, made up of representatives from universities, industry and the government, says good quality data were not generally available, although two new monitoring networks have recently been established.

K.J.

\section{AIDS tests in India}

THE Indian health ministry has announced that all foreigners intending to stay for more than a year in India will have to undergo tests for AIDS (acquired immune deficiency syndrome). The rule does not, however, apply to diplomats and their staff or to journalists.

AIDS screening is at present compulsory only for foreign students. Official sources said that the decision to extend this to all foreigners staying longer than a year was taken to placate the foreign students, mostly Africans, who have been complaining that India's AIDS policy was discriminatory. 